PEMBELAJAR: Jurnal Ilmu Pendidikan, Keguruan, dan Pembelajaran

Volume 3 Nomor 1 April 2019

e-ISSN: 2549-9114 dan p-ISSN: 2549-9203

(Received: Januari 2019 ; Reviewed: Februari -2019; Published: April 2019)

DOI: https://doi.org/10.26858/pembelajar.v3i1.8649

\title{
Minat Belajar Mahasiswa dengan Menggunakan Blended Learning melalui Google Classroom pada Pembelajaran Konsep Dasar Bahasa Indonesia SD
}

\author{
Feby Inggriyani ${ }^{a}$, Acep Roni Hamdani ${ }^{b}$, Taufiqulloh Dahlan ${ }^{c}$ \\ $\mathrm{a}, \mathrm{b}, \mathrm{c}$ PGSD FKIP Universitas Pasundan \\ Corresponding e-mail: febyinggriyani@unpas.ac.id
}

\begin{abstract}
Abstrak: Penelitian ini menggunakan metode kualitatif dengan desain deskriptif. Tujuan dari penelitian ini adalah untuk mengidentifikasi minat belajar mahasiswa dengan blended learning menggunakan kelas google. Populasi dalam penelitian ini adalah siswa semester empat tahun akademik 2018/2019. Pengambilan sampel dengan purposive sampling adalah kelas IV A yang berjumlah 44 orang. Teknik pengumpulan data menggunakan triangulasi, yaitu kuesioner, wawancara dan observasi. Hasil penelitian menunjukkan bahwa rata-rata minat belajar mahasiswa sebelum blended learning adalah 66,70. Sedangkan hasil rata-rata skor minat mahasiswa setelah diberikan pembelajaran dengan memanfaatkan blended learning, yaitu 85,48. Dengan demikian, ada peningkatan minat dalam belajar dengan rata-rata 18,78. Semua indikator minat belajar siswa dicapai dengan sangat baik. Indikator persentase perasaan senang adalah 86,50, indikator perhatian saat belajar adalah 85,80 , indikator minat belajar adalah $85,00 \%$ dan indikator keterlibatan dalam belajar adalah $84,50 \%$. Indikator minat belajar terbesar adalah perasaan bahagia. Dengan demikian, blended learning dapat meningkatkan minat belajar di perguruan tinggi.
\end{abstract}

Kata Kunci: blended learning, google classroom, minat belajar

Abstract: This study uses qualitative methods with descriptive designs. The purpose of this study is to identify interest in college student learning in blended learning using google classes. The population in this study is the fourth semester students of the 2018/2019 academic year. Sampling with purposive sampling is class IV A, amounting to 44 people. Data collection techniques using triangulation, namely questionnaires, interviews and observations. The results showed that the average college student learning interest before blended learning was 66.70. While the results of the average score of interest in college student after being given learning by utilizing blended learning, which is 85.48 . Thus, there is an increased interest in learning with an average of 18.78. All student learning interest indicators are very well achieved. The indicator of the percentage of feeling happy is 86.50 , the indicator of attention when studying is 85.80 , the indicator of learning interest is $85.00 \%$ and the indicator of involvement in learning is $84.50 \%$. The indicator of greatest interest is feeling happy. Thus, blended learning can increase interest in studying in college.

Keywords : blended learning, google classroom, lerning interest

(O2019 -Pembelajar Universitas Negeri Makassar. Ini adalah artikel dengan akses terbuka dibawah licenci CC BY-NC-4.0 (https://creativecommons.org/licenses/by-nc/4.0/ ).

\section{PENDAHULUAN}

Proses pembelajaran memiliki peran penting dalam meningkatkan kualitas pendidikan, sehingga pembelajaran akan lebih bermakna dan bermanfaat bagi mahasiswa. Oleh karena itu, dosen harus memperhatikan media penujang sehingga pembelajaran lebih kondusif dan bermakna dengan mengarahkan pada aktivitas modernisasi melalui bantuan teknologi canggih yang dapat membantu mahasiswa dalam memahami materi pelajaran secara interaktif, efektif, dan menyenangkan.

Pembelajaran dengan menggunaan kemajuan teknologi ini dapat memberikan pengaruh yang signifikan terhadap dunia pendidikan untuk menunjang kegiatan proses pembelajaran. Penguasaan dosen dan mahasiswa 
didalam menggunakan TIK pun menjadi hal yang sangat penting dalam rangka menghadapi persaingan global yang menuntut mahasiswa untuk memiliki minat didalam belajar sehingga mempu untuk mandiri, keatif, berpikir kritis dan mampu memecahkan masalah sesuai dengan tuntutan abad 21 menggunakan pembelajaran berbasis teknologi blended learning.

Blended learning merupakan salah satu solusi untuk memecahkan masalah yang bisa dilaksanakan dosen dalam proses pembelajaran. Thorne dalam (Sjukur, 2012:370) menjelaskan bahwa blended learning adalah kegiatan pembelajaran yang mengintegrasikan atau menggabungkan inovasi dan teknologi dengan interaksi dan partisipasi pembelajaran konvensional. Hal ini sesuai dengan pendapat Torraro (2007) yang menjelaskan bahwa blended learning adalah pembelajaran yang menggabungkan antara pembelajaran tatap muka (face to face) dan pembelajaran elektronik (e-learning). Pembelajaran e-learning dapat melatih mahasiswa untuk belajar mandiri sehingga dapat membuat dirinya memiliki minat dalam belajar. Selain itu, mahasiswa dapat memperkuat pengetahuannya dengan cara mencari sendiri pengetahuan yang mereka butuhkan melalui fasilitas internet dengan arahan dosen. Pertemuan tatap muka pun diperlukan agar dosen dan mahasiswa lebih dekat dan saling mengenal satu sama lain. Selain itu, dosen pun dapat memantau respon mahasiswa dalam pembelajaran during. Dengan demikian, blended learning adalah penggabungkan pembelajaran konvensional dan daring. Hal ini dilakukan dengan tujuan supaya pembelajaran yang diberikan dosen dapat tercapai. Penggunaan e-learning dapat memberikan fleksibilitas, interaktivitas, kecepatan dan visualisasi melalui berbagai kelebihan dari masing-masing teknologi yang digunakan.

Berdasarkan hasil pengamatan pada mahasiswa PGSD semester IV mata kuliah konsep dasar bahasa Indonesia SD, masih terdapat mahasiswa yang tidak fokus didalam pembelajaran, rendahnya kemandirian belajar mahasiswa dan kemampuan berpikir kritis mahasiswa sehingga pembelajaran tidak kondusif dan mahaiswa kurang memiliki minat untuk belajar.

Minat belajar sangat penting dalam proses pembelajaran, karena minat merupakan salah satu faktor internal yang mempengaruhi pembelajaran. Slameto $(2010: 180)$ menjelaskan bahwa minat adalah suatu kecenderungan tetap pada seseorang untuk memperhatikan suatu kegiatan yang disukai sehingga mampu memperhatikan secara terus-menerus, puas dan ketertarikan pada suatu hal atau aktivitas, tanpa adanya suruhan dari orang lain. Didalam pembelajaran, ketika mahasiswa tidak berminat untuk belajar, maka akan menimbulkan suasana pembelajaran yang tidak kondusif. Minat belajar menurut Qomariah dan I Ketut R.S (2016:42) merupakan perasaan suka atau ketertarikan peserta didik terhadap pelajaran sehingga mendorongnya untuk mempelajari dan menguasai pengetahuan serta pengalaman dengan ditunjukkan melalui partisipasi dan keaktifan dalam mencari pengetahuan dan pengalaman tersebut. Oleh karena itu, minat belajar akan mendorong mahasiswa untuk belajar lebih baik lagi dengan adanya ketertarikan atau suka pada pelajaran sehingga memiliki inisiatif untuk terus belajar dan merasa sangat bermanfaat baginya.

Kegiatan belajar mengajar akan berjalan secara efektif dan efisien jika mahasiswa memiliki minat yang tinggi untuk belajar. Indikator minat belajar menurut oleh Djamarah (2011) terdiri dari, 1) Perasaan senang terhadap suatu kegiatan tanpa paksaan untuk mempelajarinya, 2) Ketertarikan siswa pada kegiatan atau bisa berupa pengalaman yang dirangsang oleh kegiatan itu sendiri, 3) Perhatian siswa dengan melakukan konsentrasi atau aktivitas terhadap pengamatan tertentu, dan 4) Keterlibatan siswa pada suatu objek yang mengakibatkan orang tersebut senang untuk belajar dan merasa tertarik untuk melakukan atau mengerjakan kegiatan pembelajaran yang diberikan.

Istiqomah dan Ninik (2013:109) menjelaskan bahwa salah satu yang dapat meningkatkan minat belajar mahasiswa adalah penggunaan metode pembelajaran yang tepat. Misalnya, dosen memanfaatan penggunaan internet didalam pembelajaran. Oleh karena itu, perlu diupayakan terobosan pembelajaran untuk meningkatkan minat belajar dan hasil belajar mahasiswa melalui penggunaan media pembelajaran berbasis e-learning dan tatap muka. Prakoso, J.S Sukardjo, dan Sri (2013:100) menjelaskan bahwa penggunaan blended learning dapat meningkatkan minat dan hasil belajar pada materi kelarutan dan hasil kali kelarutan. Salah satu penggunakaan blended learning adalah google classroom.

Aplikasi google ini dapat diakses di PC dan dapat diakses melalui ponsel atau tablet yang berbasis android/iOS. Dosen dan mahasiswa dapat mengunjungi situs https://classroom.google.com di google atau dapat mengunduhnya melalui playstore di android. Penggunaannya pun tanpa dipungut biaya, sehingga pemanfaatannya dapat dilakukan sesuai kebutuhan. Pembelajaran dengan menggunakan aplikasi google classroom ini dapat menghubungkan dosen dan mahasiswa 
secara digital dan dapat menghemat waktu, karena dapat diakses dimanapun dan kapanpun dengan menggunakan koneksi internet.

Izenstark dan Leahy (2015) menjelaskan bahwa desain dari google classroom sudah tidak asing lagi bagi siswa karena mereka sudah menggunakan beberapa produk dari google via akun. Google Apps memiliki konektivitas antara google classroom dengan akun google drive sehingga tidak perlu khawatir untuk menyimpan dokumen-dokumen dalam komputer. Dalam proses pembelajaran pun mahasiswa diberikan penugasan oleh dosen dan mengirimkan hasil laporannya ke aplikasi google classroom. Selain itu, mahasiswa diberikan materi tambahan guna memahami lebih luas materi yang mungkin belum bisa tersampaikan langsung ketika di kelas.

Kelebihan google classroom menurut Janzem dalam Iftakhar (2016:13) yaitu mudah digunakan, dapat menghemat waktu, berbasis cloud, bersifat fleksibel kapan saja dan dimana saja bisa digunakan, dan tidak berbayar (gratis). Sedangkan kelemahannya tidak ada layanan eksternal seperti bank soal secara otomatis dan obrolan secara pribadi antara guru dan siswa untuk mendapat umpan balik (Pappas, 2015).

Tujuan pembelajaran dengan aplikasi google classroom adalah untuk lebih mudah direalisasikan dan sarat akan kebermaknaan sehingga dapat mempermudah guru dalam mengelola pembelajaran dan menyampaikan informasi secara tepat dan akurat kepada siswa (Hardiyana,2015). Dengan demikian, melalui google classroom, dosen dapat memberikan informasi seputar mata kuliah dari memberikan tugas hingga mengumpulkannya di google classroom, mengupload daftar nilai, pengumuman info perkuliahan, pembagian kelompok kerja dan upload materi ajar.

Berdasarkan permasalahan dan kondisi di atas, maka peneliti tertarik untuk melakukan pengkajian lebih mendalam mengenai Minat Belajar Mahasiswa dengan Menggunakan Blended Learning melalui Google Classroom pada Pembelajaran Konsep Dasar Bahasa Indonesia SD.

\section{METODE}

Metode ini menggunakan jenis penelitian deskriptif untuk mendeskripsikan fenomena atau peristiwa secara sistematis sesuai dengan apa adanya dan kondisi di lapangan. Data yang digunakan dalam penelitian ini adalah data kualitatif deskriptif. Tempat penelitian berlokasi di Program Studi PGSD Fakultas Keguruan dan Ilmu Pendidikan Universitas Pasundan.
Populasi dalam penelitian ini adalah mahasiswa semester IV program studi PGSD tahun pelajaran 2017/2018.Pengambilan sampel dilakukan dengan teknik purposive sampling yaitu cara pengambilan sampel berdasarkan pertimbangan tertentu. Alasan penentuan sampel disesuaikan dengan jadwal perkuliahan. Sampel yang digunakan adalah mahasiswa semester IV A yaitu 44 orang.

Pengumpulan data dalam penelitian ini adalah angket untuk mendapatkan data minat belajar mahasiswa, wawancara dan observasi. Hasil minat belajar mahasiswa menggunakan rumus persentase dari hasil pengumpulan data menggunakan angket. Instrumen angket minat belajar menggunakan angket yang sudah valid melalui expert judjement dan uji coba soal dengan menggunakan skala likert. Teknik pengumpulan data menggunakan triangulasi, yaitu kuesioner, wawancara dan observasi.

Ridwan (2006:88) menjelaskan mengenai kriteria interpretasi skor untuk Tingkat Capaian Responden adalah sebagai berikut:

Tabel 1. Rentang Skala Tingkat Capaian Responden

\begin{tabular}{ccc}
\hline No & Angka & Keterangan \\
\hline 1 & $00 \%-20 \%$ & Sangat lemah \\
\hline 2 & $21 \%-40 \%$ & Lemah \\
\hline 3 & $41 \%-60 \%$ & Cukup \\
\hline 4 & $61 \%-80 \%$ & Kuat \\
\hline 5 & $81 \%-100 \%$ & Sangat kuat \\
\hline
\end{tabular}

\section{HASIL DAN PEMBAHASAN}

Data minat belajar mahasiswa diperoleh dari hasil angket minat belajar yang diberikan kepada mahasiswa sebelum dan setelah dilakukan pembelajaran dengan menggunakan blended learning melalui google classroom. Berdasarkan hasil analisis data diperoleh bahwa rata-rata minat belajar mahasiswa sebelum pembelajaran blended learning sebesar 66,70. Sedangkan hasil rata-rata skor minat belajar setelah diberikan pembelajaran dengan memanfaatkan blended learning, yaitu 85,48. Dengan demikian, terdapat peningkatan rata-rata minat belajar mahasiswa sebesar 18,78 . Berikut dijabarkan deskripsi minat belajar mahasiswa sebelum dan sesudah pembelajaran menggunakan blended learning. 


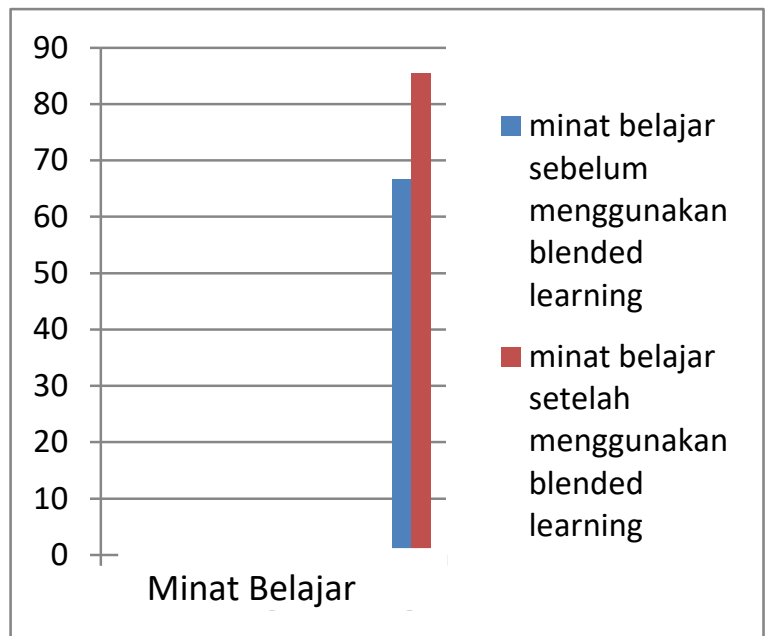

\section{Gambar 1. Pre tes dan post test minat belajar mahaiswa menggunakan blended learing melalui google classroom}

Interprestasi hasil angket minat belajar setelah menggunakan model blended learning melalui google classroom adalah sangat kuat dengan rata-rata interprestasi minat belajar $85,48 \%$. Dengan demikian, menunjukkan bahwa mahasiswa memiliki minat belajar konsep dasar bahasa Indonesia SD pada materi morfologi dengan menggunakan pembelajaran model blended learning melalui google classroom. Hal ini sesuai dengan penelitian Hermidayani dan Khoirun (2018) yang menjelaskan bahwa ratarata hasil belajar ekonomi yang memperoleh perlakuan model blended learning lebih tinggi daripada yang belajar dengan pembelajaran langsung atau tatap muka. Hal ini dikarenakan penggunaan blended learning menggabungkan antara pembelajaran secara konvensional (face to face) dengan e-learning. Dalam pembelajaran tersebut, tidak menggantikan belajar tatap muka di kelas, melainkan e-learning dapat memperkuat didalam pemberian materi pembelajaran sehingga mahasiswa bias bertukar pendapat dan belajar lewat online. Selain itu, blended learning dapat membuat mahasiswa menempatkan dirinya sebagai pembelajar yang aktif didalam memahami kebutuhannya dan berupaya mencapai pemahaman secara mandiri. Angket minat dalam penelitian ini terdiri dari 4 aspek yaitu 1) perasaan senang, 2) perhatian, 3) keterlibatan aktif dalam pembelajaran dan 4) ketertarikan mahasiswa. Aspek tersebut dijabarkan menjadi beberapa indikator.

Indikator perasaan senang mahasiswa. Rata-rata interprestasi perasaan senang mahasiswa belajar dengan menggunakan blended learning melalui google classsrom sebesar 86,50 \% dengan kategori sangat kuat. Ini menunjukkan bahwa mahasiswa merasa senang dengan pembelajaran yang dilakukan dosen yaitu tatap muka di kelas untuk lebih memahami materi yang diberikan dan pengayaan atau pemberian tugas serta pemberian materi dengan menggunakan google classroom sehingga pembelajaran lebih efisien dan efektif yang mengakibatkan mahasiswa tidak hanya belajar di kelas saja. Mahasiswa bisa bertanya dan belajar dari media internet untuk memahami materi yang diberikan dosen sehingga dapat menghemat dari segi waktu. Hal ini sesuai dengan penelitian Bibi (2015:283) yang mengatakan bahwa pelaksanaan blended learning efisien dari segi waktu karena pemberian materi yang diberikan sifatnya mandiri bagi mahasiswa dengan diawali minat dalam belajar. Materinya pun memerlukan penjelasan khusus dengan dialokasikan pada waktu tatap muka dan untuk melakukan refleksi e-learning melalui google classroom. Hal ini membuat mahaisswa merasa senang karena bisa belajar selain di kelas dan dapat dengan mudah memahami materi yang diberikan.

Berdasarkan hasil wawancara dan observasi dengan pada mahasiswa, diperoleh informasi bahwa mahasiswa senang belajar dengan menggunakan blended learning melalui google classroom. Ini dikarenakan proses pembelajaran yang tidak hanya dengan tatap muka di kelas saja, namun juga ada $e$ learningnya.Selain itu, pembelajarannya pun tidak menyusahkan, karena mahasiswa dapat dengan mudah mengaksesnya baik dari komputer maupun dari hp android dengan bantuan internet sehingga mahasiswa senang apalagi dengan kebiasaan mahasiswa yang tiap harinya aktif dengan gadget dan media online.

Indikator perhatian mahasiswa belajar dengan menggunakan blended learning melalui google classroom, rata-rata interprestasinya sebesar 85,80 \% dengan kategori sangat kuat. Hal ini menunjukkan bahwa mahasiswa memberikan perhatian terhadap pembelajaran yang dilakukan ketika tatap muka di kelas dan pada tugas tambahan atau pemberian materi blended learning melalui google classroom. Selain itu, penggunaan google classroom sangat mudah karena mirip dengan facebook sehingga tidak mempersulit mahasiswa untuk melakukan pembelajaran secara online dan merupakan pembelajaran baru dan menarik sehingga mahasiswa memberikan perhatian terhadap pembelajaran yang diberikan. Hal ini sesuai dengan pendapat Pohan (2016:33) yang menjelaskan bahwa blended learning akan memancing siswa untuk memiliki rasa ingin tahu yang lebih terhadap materi yang dibahas saat proses pembelajaran menggunakan media komputer atau laptop.

Berdasarkan hasil wawancara dan observasi dengan mahasiswa, mandapatkan 
informasi bahwa belajar dengan blended learning membuat mahasiswa memperhatikan pembelajaran. Hal ini diakibatkan kmbelajaran tidak hanya di kelas melainkan adanya pembelajaran secara online sehingga mahasiwa perlu untuk memberikan perhatian penuh didalam belajar dan adanya perhatian tersebut karena mahasiswa merasa senang dan tertantang mengikuti kegiatan pembelajaran baik di kelas maupun didalam classroom. Selain itu, setiap materi yang diberikan di classroom memudahkan didalam memahaminya dengan cara membacanya secara beruang-ulang dan mengerjakan tugas atau kuis dengan tepat waktu yang sudah ditentukan di google classroom.

Indikator ketertarikan mahasiswa dalam pembelajaran dengan mengunakan blended learning melalui classroom learning yaitu ratarata interprestasi 85,00 \% dengan kategori sangat kuat. Hal ini menunjukkan bahwa mahasiswa tertarik ketika belajar baik di kelas dengan tatap muka maupun pada pembelajaran melalui google classroom. Hal ini sesuai dengan penelitian (Nanundyta, 2018) yang menjelaskan bahwa proses pembelajaran lebih menyenangkan dengan menggunakan model blended learning sehingga siswa tertarik untuk mengikuti proses pembelajaran.

Berdasarkan hasil wawancara dengan mahasiswa, menunjukkan bahwa mereka sangat tertarik dan puas dengan pembelajaran yang dilakukan dikarenakan adanya perpaduan antara belajar biasa di kelas dengan penggunaan google classroom sebagai e-learning. Selain itu, mahasiswa menyukai model blended learning melalui google classroom karena praktis dan mudah digunakan. Hal tersebut sesuai dengan hasil penelitian Gunawan dan Stefani (2018:346) menjelaskan bahwa pembelajaran dengan menggunakan google classroom secara perlahan akan membuat siswa merasa terbantu untuk memahami materi pembelajaran dikarenakan pembelajaran tidak dibatasi oleh waktu, sehingga siswa dapat belajar pada waktuwaktu tertentu dalam artian tidak terkurung oleh waktu pada saat jam pelajaran, sehingga soal yang dirasakan sulit tersebut dapat dikerjakan dalam waktu yang lebih lama. Hal ini menunjukkan bahwa mahasiswa ingin berlamalama belajar konsep dasar bahasa Indonesia SD jika diajarkan dengan model blended learning. Mahasiswa pun tertarik untuk mengamati penjelasan dosen saat tatap muka karena merasa tertarik dengan model blended learning melalui google classroom maupun pada saat pembelajaran di rumah dengan goole classroom. Hal ini sesuai dengan pendapat Iftakhar (2016) yang menjelaskan bahwa google classroom membantu untuk memonitoring siswa untuk belajar. Guru dapat melihat seluruh aktivitas siswa selama pembelajaran di google classroom. Interaksi antara guru dan siswa terekam dengan baik sehingga mempermudah untuk mengetahui diskusi yang dilakukan didalam classroom.

Gunawan dan Stefani (2018:345) menjelaskan bahwa pembelajaran dengan menggunakan google classroom akan efektif karena dapat melihat tingkat kesalahan yang dibuat oleh siswa saat menyelesaikan permasalahan yang diberikan, sehingga menjadi acuan. Selain itu, pada saat dosen memotivasi siswa untuk mempelajari materi yang telah diunggah ke dalam kelas google classroom untuk mengerjakan soal test serta keefektifan pembelajaran tersebut dapat dilihat berdasarkan ketepatan waktu yang dipergunakan oleh siswa untuk belajar, mengunggah hasil test serta mengunggah hasil kuesioner melalui kelas google classroom. Dengan demikina, penerapan menggunakan blended learning dapat melengkapi dan mengatasi materi yang belum tersampaikan pada saat proses pembelajaran. Selain itu, blended learning bermanfaat untuk mengembangkan dan menanamkan keterlibatan mahasiswa pada proses perkuliahan sehingga mahasiswa menjadi minat didalam belajar, terlatih untuk aktif mengikuti pembelajaran dan dosen dapat menyediakan latihan soal dan kuis yang dapat dimanfaatkan oleh mahasiswa di dalam google classroom. Adapun dosen harus segera memberikan feedback berupa skor yang diperoleh mahasiswa untuk segera langsung diketahui dengan memberikan komentar terhadap hasil karyanya. Dengan demikian, pembelajaran dengan menggunakan google classroom dapat membantu mahasiswa untuk mengetahui kesalahan dalam memahami materi sehingga memacunya untuk belajar lebih giat lagi dalam pembelajaran.

Indikator mengenai keterlibatan belajar mahasiswa rata-ratanya sebesar $84,50 \%$. Ini menunjukan bahwa mahasiswa ikut terlibat dalam pembelajaran dengan menggunakan blended learning sangat kuat. Berdasarkan hasil observasi, ketika pembelajaran tatap muka mahasiswa terlihat mengamati dengan seksama penjelasan teman di depan kelas, mengikuti instruksi yang diberikan oleh dosen seperti ketika dosen meminta mahasiswa untuk berdiskusi tentang kesulitan mahasiwa pada materi, memberikan kesimpulan, mengerjakan kuis, serta mengunggah cara pengerjaan kuis di google classroom. Selain itu, sebagian mahasiswa terlihat diam saat dosen menanyakan tentang materi yang belum dimengerti mengenai morfologi, seolah-olah mahasiswa sudah memahaminya. Adapun, hasil wawancara dengan mahasiswa menyatakan bahwa alasan 
tidak mau bertanya kepada dosen pada saat tatap muka disebabkan karena mahasiswa merasa malu untuk bertanya takutnya ditertawakan oleh temannya dan ada sebagian yang belum memahaminya. Sedangkan pada saat diskusi online menggunakan googe classroom, siswa tampak tidak malu bertanya mengenai kesulitankesulitan yang dialami pada materi morfologi. Dengan adanya diskusi online, siswa lebih merasa memiliki hak untuk bebas bertanya (Salma, 2004). Hal ini sesuai dengan hasil penelitian Istiqomah dan Ninik (2013:109) yang menjelaskan bahwa penerapan metode blended learning pada perkuliahan ISBD sangat berpengaruh positif pada peningkatan aktifitas belajar mahasiswa. Terlihat pada aktivitas perkuliahan mahasiswa yang sudah lebih baik dan mengalami peningkatan, sehingga hampir semua mahasiswa antusias dan merasa senang mengikuti perkuliahan dengan memanfaatkan aplikasi classroom. Selain itu, dosen dapat menyampaikan hasil penilaian langsung melalui classroom dan dapat diakses dengan mudah oleh semua mahasiswa sehingga dapat menumbuhkan minat mahasiswa dan semakin termotivasi untuk beruha memperbaikinya supaya mendapatkan nilai yang terbaik dari semua tes ujian yang diberikan dosen.

Berdasarkan diskusi online menggunakan google classroom, mahasiwa tampak saling menanggapi pernyataan dari temannya sehingga terjadinya keterlibatan aktif dalam pembelajaran. Tidak hanya dosen yang menanggapi pernyataan mahasiswa lain yang remedial dikelompoknya, tetapi mahsiswa yang remedial juga ikut menanggapi pernyataan teman-temannya. Hal ini menunjukkan bahwa siswa tidak malu menjawab pertanyaan yang diberikan oleh dosen dengan pembelajaran model blended learning berbasis google classroom.

Berikut interpretasi dari masing-masing indikator minat belajar mahasiswa dengan menggunakan blended learning.

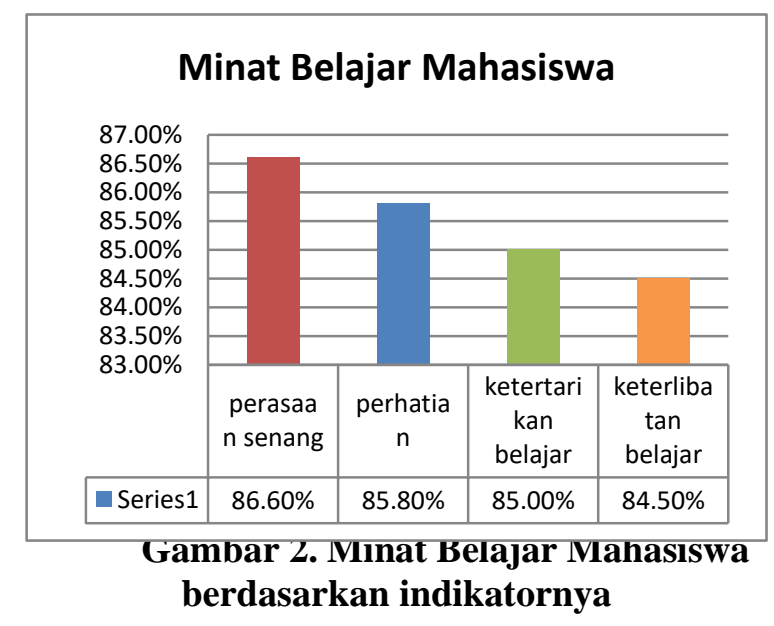

Berdasarkan tabel di atas dapat dilihat bahwa indikator hasil persentasi perasaan senang sebesar $86,60 \%$, perhatian sebesar $85,80 \%$, ketertarikan belajar sebesar $85,00 \%$, dan keterlibatan sebesar $84,50 \%$. Indikator yang paling besar adalah perasaan senang mahasiswa didalam belajar dengan menggunakan blended learning. Hal ini menunjukkan bahwa minat belajar seseorang akan terbangun atau terbentuk apabila menyukai suatu kegiatan yang ditekuninya dengan penuh rasa senang dan tanpa adanya paksaan dari orang lain sehingga nyaman ketika belajar serta tidak adanya beban untuk belajar. Indikator perhatian juga memperoleh nilai persentase yang besar yaitu $85,80 \%$. Ini menunjukkan bahwa ketika mahasiswa merasa senang, maka akan memberikan perhatian yang lebih didalam belajar apalagi dengan adanya tuntutan untuk mengerjakan tugas secara online. Indikator ketertarikan belajar sebesar $85.00 \%$. Hal ini menunjukan bahwa ketika sesorang tertarik pada media atau metode pembelajaran yang diberikan oleh dosen, maka ia akan semangat untuk mempelajarinya dan merasa tertangtang untuk belajar serta akan memudahkan mahasiswa untuk mempelajari materinya. Adapun persentase nilai keterlibatan mahasiswa dalam belajar paling rendah diantara yang lainnya. Hal ini disebabkan karena dalam pembelajaran berbasis blended learning melalui google classroom mahasiswa harus memiliki kemampuan aktif dalam berinteraksi di internet dengan mengerjakan kuis dan tugas yang diberikan dosen dan mahasiswa yang pasif didalam membuka situs google dan mengerjakan tugas dengan tidak tepat waktu merasa ketinggalan sehingga keterlibatannya dalam proses pembelajaran menjadi berkurang.

\section{KESIMPULAN}

Berdasarkan analisis data yang diperoleh dari hasil angket minat mahasiswa, dapat disimpulkan bahwa minat belajar mahasiswa setelah dilakukan pembelajaran dengan model blended learning melalui google classroom sangat kuat dengan rincian rata-rata interprestasi minat berdasarkan aspek-aspeknya, yaitu 1) aspek perasaan senang dengan kategori sangat kuat, 2) perhatian dengan kategori sangat kuat dan 3) terlibat aktif dengan kategori sangat kuat dan ketertarikan belajar mahasiswa sangat kuat. Dari hasil analisis tersebut, indikator perasaan senang paling tinggi dibandingkan indikator yang lainnya. Ha ini menyebabkan mahasiswa merasa nyaman ketika belajar dan dapat dengan mudah untuk memahami materi yang diberikan dosen. Sedangkan indikator keterlibatan ketika pembelajaran paling sedikit dibandingkan 
indikator yang lainnya karena didalam pelaksanaan blended learning diperlukan keterlibatan penuh baik didalam pembelajaran tatap muka maupun pembelajaran e-learning dengan classroom

Adapun saran peneliti terkait dengan hasil penelitian ini yaitu (1) dosen dapat menerapkan blended learning untuk meningkatkan minat dan melatih kemandirian belajar mahasiswa (2) dosen lebih aktif berinteraksi dengan mahasiswa yang kurang aktif baik di dalam kegiatan tatap muka maupun pembelajaran online, (3) disarankan untuk memberi renggang waktu beberapa hari kepada mahasiswa untuk mengerjakan tugas secara online, supaya dosen dapat memprediksi waktu yang dibutuhkan mahasiwa dalam menuliskan apa yang ingin disampaikan, 4) dosen atau peneliti lain ketika menerapkan blended learning disarankan untuk memperhatikan koneksi internet dan mencoba aplikasi selain google classroom yang lebih terbaru dan lebih lengkap fiturnya.

\section{UCAPAN TERIMA KASIH}

Penelitian ini didukung oleh Pusat Penelitain FKIP Universitas Pasundan tahun 2018. Penulis mengucapkan terima kasih kepada Pusat Penelitian FKIP Universitas Pasundan dan semua orang yang telah terlibat dalam memberikan dukungan dan arahan sehingga penelitian ini bisa berjalan dengan lancar dengan tepat waktu.

\section{DAFTAR PUSTAKA}

Bibi, Sarah. (2015). Efektivitas Penerapan Blended Learning Terhadap Tingkat Pemahaman Mahasiswa Mata Kuliah Algoritma Dan Pemrograman. Jurnal Pendidikan Informatika dan Sains, 4(2), 274-286.

Djamarah, Syaiful. (2011). Psikologi Belajar. Jakarta: Rineka Cipta.

Gunawan1, Fransiskus Ivan dan Stefani Geima Sunarman.(2018).Pengembangan Kelas Virtual Dengan Google Classroom Dalam Keterampilan Pemecahan Masalah (Problem Solving) Topik Vektor Pada Siswa Smk Untuk Mendukung Pembelajaran. Prosiding Seminar Nasional Pendidikan Matematik Etnomatnesia. 340-348.

Hardiyana, Andri. (2015). Implementasi Google Classroom sebagai Alternatif dalam Meningkatkan Mutu Pembelajaran di Sekolah. Karya Tulis Ilmiah, Cirebon: SMA Negeri 1 Losari.
Hermidayani, Khoirun. (2018). Pengaruh Model Blended Learning dan Minat Belajar terhadap Hasil Belajar Ekonomi. Seminar Nasional Royal (SENAR). STMIK Royal - AMIK Royal. 661 666

Iftakhar, Shampa. (2016). Google Classroom: What Works and How?. Journal of Education and Social Sciences, 3 (feb), 12-18.

Istiqomah, Sri Banun Titi \& Ninik Azizah. (2013). Penerapan Metode Blended Learning Berbasis ICT untuk Meningkatkan Minat dan Prestasi Belajar pada Mata Kuliah Ilmu Sosial Budaya Dasar (ISBD) di Prodi D-III Kebidanan FIK UNIPDU Jombang. JURNAL EDUHEALTH, 3(2), 103113.

Izenstark, Amanda, and Katie L. Leahy. (2015).

"Google Classroom for Librarians: Features and Opportunities." Library Hi Tech News $32 \quad$ (9):1-3. https://doi.org/10.1108/LHTN-05-20150039.

Nanindya, D. W. 2018. Daya Tarik Pembelajaran DI Era 21 dengan Blended Learning. JKTP, I (1): 13-18

Pappas, Christopher (2015). "Google Classroom Review: Pros And Cons Of Using Google Classroom In eLearning". Diakses 1 Mei 2017 dari https://elearningindustry.com/google classroom-review-pros-and-cons-ofusinggoogle-classroom-in-elearning

Pohan, Sutan Saribumi. (2016). Blended Learning Sebagai Strategi Pembelajaran Di Era Digital. Prosiding Temu Ilmiah Nasional Guru (Ting) Viii. Universitas Terbuka Convention Center. 227-237.

Jatmiko Budhi Prakosa, Jatmiko Budi, J.S Sukardjo dan Sri Mulyani.(2013). Penerapan Blended Learning Dengan Numbered Heads Together (Nht) Untuk Meningkatkan Minat Dan Prestasi Belajar Pada Materi Kelarutan Dan Hasil Kali Kelarutan Siswa Kelas Xi Ipa 1 Sma Negeri Gondangrejo Tahun Ajaran 2012/2013. Jurnal Pendidikan Kimia (JPK), 2(4), 96-101.

Qomariah, S.S dan I Ketut R.S. (2016). Kualitas Media Pembelajaran, Minat Belajar, Dan Hasil Belajar Siswa: Studi Pada Mata Pelajaran Ekonomi Di Kelas $X$ Iis Sma Negeri 12 Jakarta. Jurnal Pendidikan Ekonomi dan Bisnis, 4 (1),33-47. 
Pembelajar: Jurnal Ilmu Pendidikan, Keguruan, dan Pembelajaran. 3 (1) April 2019

Riduwan. 2006. Belajar Mudah Penelitian untuk Guru-Karyawan dan Peneliti Pemula.Bandung:Alfabeta Rosdakarya.

Salma, D. P. (2004). Mozaik Teknologi Pendidikan E-learning. Jakarta: Kencana.

Slameto. (2010). Belajar dan Faktor-faktor yang Mempengaruhinya. Jakarta: Rineka Cipta.

Sjukur, S.B.(2012). Pengaruh Blended Learning terhadap Motivasi Belajar dan Hasil Belajar Siswa Tingkat SMK. Jurnal Pendidikan Vokasi, 3 (2), 368-378.

Torrao, S. (2007). Blended Learning: Research Report \& Examples of Best Practices. Estonia. University of Tartu. 